\title{
外来がん化学療法施行患者に対する薬剤師介入による 副作用および疼痛改善効果についての定量的評価
}

\author{
若杉吉宣 ${ }^{1}$, 森井博朗 ${ }^{1}$, 須藤正朝 ${ }^{1}$, 阪中美紀 ${ }^{1}$, 野田哲史 ${ }^{1}$, 薮田直希 ${ }^{1}$ \\ 三上貴子 ${ }^{2}$ ，園田文乃 ${ }^{3}$, 河合由紀 ${ }^{3}$, 目片英治 ${ }^{3}$, 寺田智祐 ${ }^{* 1}$

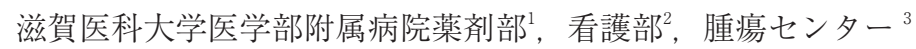

\section{Quantitative Assessment of Side Effect Management and Pain Control of Pharmacist Intervention for Patients Receiving Outpatient Chemotherapy}

Yoshinori Wakasugi ${ }^{1}$, Hiroaki Morii ${ }^{1}$, Masatomo Sudo ${ }^{1}$, Miki Sakanaka ${ }^{1}$, Satoshi Noda ${ }^{1}$, Naoki Yabuta ${ }^{1}$, Takako Mikami², Ayano Sonoda ${ }^{3}$, Yuki Kawai ${ }^{3}$ Eiji Mekata ${ }^{3}$ and Tomohiro Terada*1

Department of Pharmacy ${ }^{1}$, Department of Nursing ${ }^{2}$, Cancer Center ${ }^{3}$, Shiga University of Medical Science Hospital

$\left[\begin{array}{l}\text { Received September 1, } 2014 \\ \text { Accepted January 7, } 2015\end{array}\right]$

We carried out quantitative assessment of side effect management and pain control of pharmacist intervention for patients receiving outpatient chemotherapy. Between October 2011 and October 2012, total 3,444 chemotherapies were conducted at Shiga University of Medical Science Hospital. Of 331 chemotherapies, we intervened with side effect management, and calculated the improvement rate to compare the most severe grading of side effects or face scale (FS) between before and after pharmacist intervention. Of 331 interventions, 317 (95.8\%) prescription suggestions were adopted by physicians, of which 266 were assessable for grading or FS. Of 266 assessable interventions, 135 suggestions (50.8\%) caused significant improvement of the most severe grading score or FS, as compared to before pharmacist intervention. Improvement rate including patients' subjective symptoms was $69.5 \%$. The results of our study indicate that side effect management and pain control by pharmacist intervention could be useful for grading improvement of receiving outpatient chemotherapy.

Key words — outpatient chemotherapy, side effect management, pain control, quantitative assessment

\section{緒 言}

がん治療は近年, 新規薬剤, 新規レジメンの登 場により多岐にわたり，主治医 1 人でがん患者を フォローすることが困難になっている．また，分 子標的療法や支持療法などの進歩により，化学療 法は入院から外来へシフトしてきているのが現状 である。 2010 年 4 月 30 日付で, 厚生労働省医政 局長通知（医政発 0430 第 1 号）「医療スタッフの 協働・連携によるチーム医療の推進について」が 発出され, そのなかで薬剂師は副作用の軽減や早
期発見などにより安全な医療を提供することが期 待されている.

そのような背景のなか, 幾つかの施設で外来患 者に対して薬剂師の先進的な取り組みが行われて きている. 業務としては内服薬の服薬指導, ${ }^{1)}$ コ ンプライアンスの確認や処方支援, 副作用モニタ リング, ${ }^{2)}$ 支持療法薬の処方提案 ${ }^{2,3)}$ について報告 されている. がん化学療法施行患者では, 抗がん 剂による副作用発現により治療継続が困難な症例 も多く, 副作用を如何に抑えながら治療を続けて いけるかが課題となる。 また，がん対策基本法に

\footnotetext{
* ₹ 520-2192 滋賀県大津市瀬田月輪町
} 
おいて治療開始と同時の緩和ケア施行が推奨され ており，がん性疼痛などの疼痛管理マネジメント も必須である。

当院では腫瘍センター内に化学療法室が設置さ れており，患者が外来がん化学療法を安全に行え る体制をとっている，化学療法室には薬郕師は午 前 6 名, 午後 4 名が常駐しており, 外来がん化学 療法を施行される全患者に対して, 服薬指導や副 作用モニタリングに基づいた処方の提案を行って いる.

過去に我々は, 外来がん化学療法施行患者にお ける薬剤師の服薬指導の有用性について検討した ${ }^{4}$ が，Grade 評価を用いた定量的な評価は検討でき ていなかった。その他の報告においても限定的な 報告が多く，薬剂師が抗がん剂の副作用の全般的 マネジメントを行い，かつ定量的にその有用性を 検討したものは少ない. そこで今回, 薬剤師が行っ た処方提案について, Grade 評価, face scale (FS) 評価を用いて定量的にその有用性を評価した。

\section{方 法}

\section{1. 対象患者}

2011 年 10 月～2012 年 10 月に，当院化学療法 室にて施行された全てのがん化学療法（3,444 件） を対象とした。

\section{2. 業務手順と薬剤師の介入時点}

患者の流れと化学療法室における業務内容を図 1 に示す.

薬剤師は患者の治療薬投与中に点滴時間を利用 して介入を行った。 その際，内服薬剤のコンプラ イアンスの確認, 服薬指導, 副作用モニタリング を行い, 必要に応じて医師に対して処方提案を 行った，治療薬の投与終了後，患者は医師による 診察を受け，そこで医師は薬剤師による提案の採 否を行い，処方を決定した。

\section{3. 調査項目}

我々は 2011 年 4 月〜2011 年 8 月に当院化学療 法室にてがん化学療法を受け, 薬郕師が指導業務 を行った患者を対象に有害事象発現頻度の調査を 行った ${ }^{4)}$ 今回はその上位 10 項目（同率を含め 14 項目）を調査対象項目とした。具体的には口腔粘 膜炎，悪心，皮膚症状（ざ瘡様皮疹，皮膚乾燥， そう痒症), 神経系障害, 倦㤐感, 下痢, 便秘, 疼痛, 味覚異常, 手足症候群, 爪囲炎, 嘔吐である.

\section{4. 評価方法}

副作用は Common Terminology Criteria for Adverse Events version 4.0 （CTCAE ver.4.0）を使用し Grade 評価した。また，がん性疼痛は FS を用いて評価 した. Grade 評価および FS 評価は共に薬剤師が

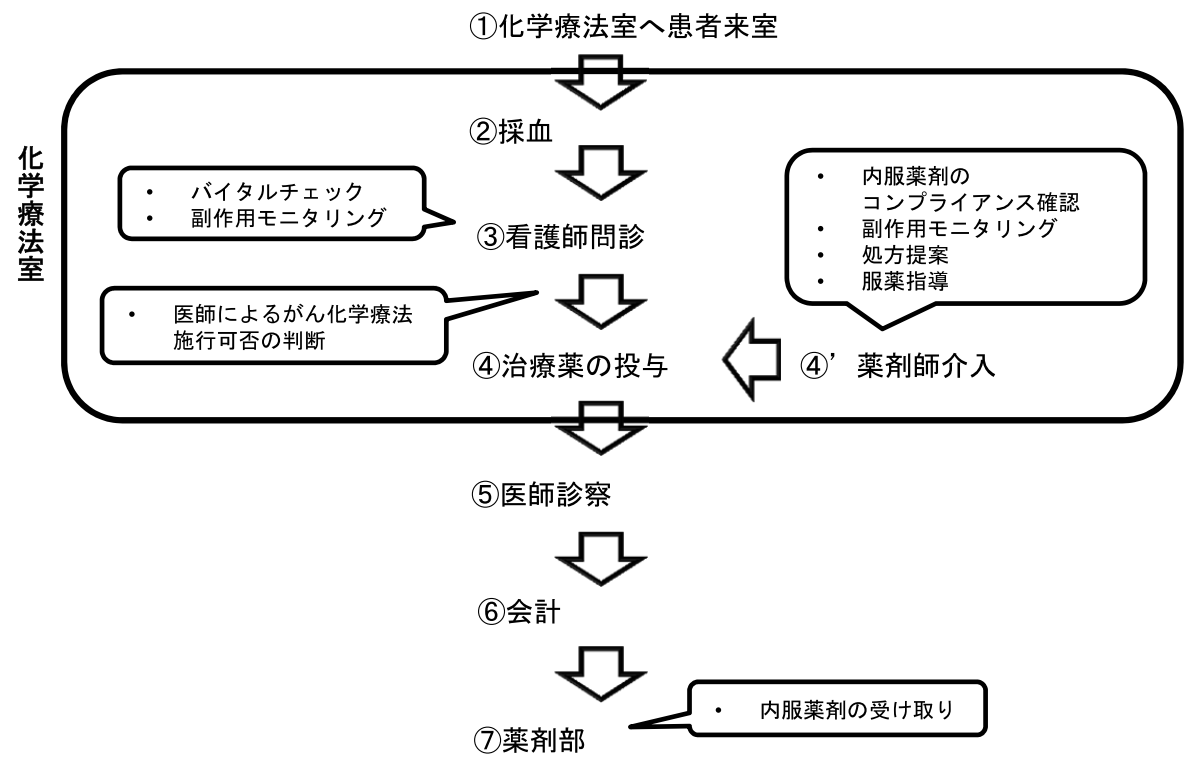

図 1 患者の流れと化学療法室における業務内容 
行った，薬剤師による処方提案の際, 各薬剤のア ルゴリズムや各学会のガイドラインを参照した. 薬殽師が提案を行った時点を境に, 直前の化学療 法のクールを「介入前」, 直後の化学療法のクー ルを「介入後」と定義し，それぞれでみられた最 低 Grade，もしくはFS を比較し，その改善率を 調査した。また，薬剤師の介入前に比べ，薬剤師 の介入後に Grade もしくは FS が低下したものを 「改善」, 変化がないものを「不変」, 上昇したも のを「悪化」と定義した.

統計解析は，対応のあるWilcoxon 検定を用い た. $P$ 值は $P<0.05$ を統計学的有意とした。また, Grade や FS が薬剤師の処方提案前後で不変の場 合, 自覚症状の改善の有無についても調査した.

\section{5. 倫理的配慮}

本調査は, 滋賀医科大学倫理委員会の承認を得 て，倫理的側面に配慮して行った（承認番号： 25-138).

\section{結果}

\section{1. 薬剤師による有害事象改善のための処方提案 とその評価}

調査期間中の外来がん化学療法の施行件数は 3,444 件であり, そのうち薬剤師による処方提案 件数は 331 件（9.6\%）であった。提案した処方 のうち，317件（95.8\%）が採用された。評価は 採用された処方件数のうち, 薬剤師介入後の評価 が可能であった 266 件を対象とした，その内訳は 口腔粘膜炎 37 件, 悪心 36 件, 皮虐症状 30 件（ざ 瘡様皮疹, 皮膚乾燥, そう痒症), 神経系障害 29 件, 倦㤐感 28 件, 下痢 27 件, 便秘 21 件, 疼痛 15 件, 味覚異常 14 件, 手足症候群 12 件, 爪囲炎 11 件, 嘔吐 6 件である.

退院などの理由により追跡不可能な事例は除外 した.

\section{2. 薬剤師介入前と薬剤師介入後の化学療法によ る副作用の Grade の変動および FS の変動}

薬剤師介入前と薬剂師介入後の化学療法による 副作用の Grade の変動および FS の変動について

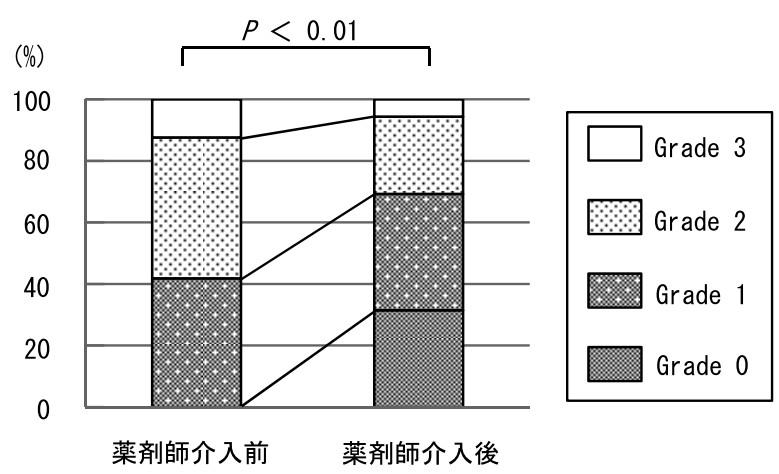

図 2 薬剤師介入前と薬剤師介入後の化学療法によ る副作用の Grade の変動

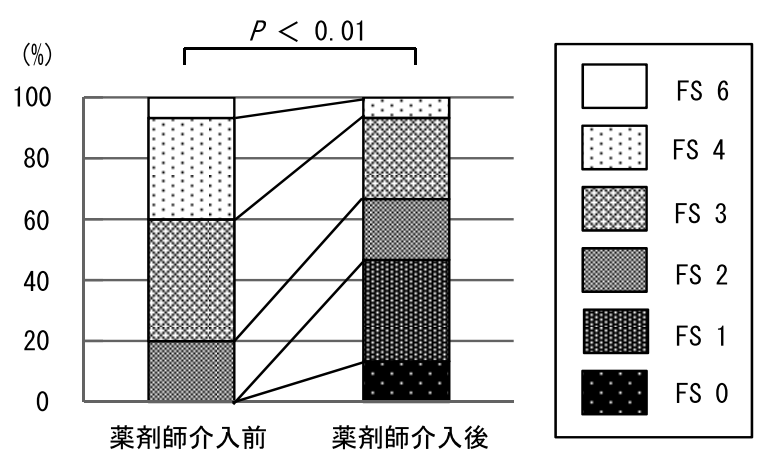

図 3 薬剂師介入前と薬剂師介入後の FS の変動 FS: face scale

それぞれ図 2, 図 3 に示す。副作用の Grade の内 訳は, 薬剤師介入前は, Grade 1 が 105 件 (41.8\%), Grade 2 が 115 件 ( $45.8 \%)$, Grade 3 が 31 件 (12.4\%) であった. 薬片師介入後は Grade 0が 79件 (31.5\%), Grade 1 が 95 件 (37.8\%), Grade 2 が 63 件 (25.1\%), Grade 3 が 14 件 (5.6\%) であったまた，FS の内 訳は，薬剂師介入前は，FS 2 が 3 件 (20.0\%), FS 3 が 6 件 (40.0\%), FS 4 が 5 件 (33.3\%), FS 6 が 1 件（6.7\%）であった. 薬剤師介入後は FS 0 が 2 件 (13.3\%), FS 1 が 5 件 (33.3\%), FS 2 が 3 件 (20.0\%), FS 3 が 4 件 (26.7\%), FS 4 が 1 件 (6.7\%) であった。薬剤師介入前と薬剤師介入後の Grade およびFS の改善度の解析を行った結果, 薬剤師 介入後では, 薬剤師介入前に比べて Grade, FS い ずれのスコアも有意な改善が認められた。

\section{3. 全体の Grade, FS 改善率および自覚症状を 含めた評価}

薬剂師介入後の全体の Grade, FS 改善率につ いて図 4 に示す。処方提案が採用された事例の 


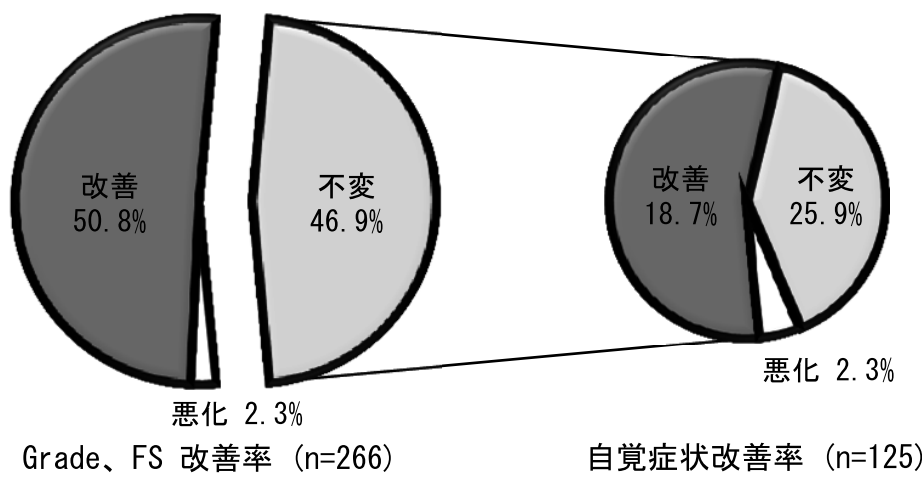

図 4 全体の Grade, FS 改善率および自覚症状を含めた評価 FS: face scale

うち, 半数以上に Grade もしくは FS の改善が認 められた．266件のうち， Grade 評価もしくは FS 評価で「不変」であった事例は 125 件であり，自 覚症状の改善は 50 件（18.7\%）に認められた。 Grade 評価, FS 評価で「改善」であった事例 （50.8\%）を合わせると，処方提案が採用された 事例の $69.5 \%$ で改善が得られた。

\section{4. 調査対象項目別の Grade, FS 改善率}

調查対象項目別の Grade, FS 改善率を表 1 に 示す, 疼痛, 口腔粘膜炎, 皮膚症状については改 善率が上位であった。しかし, 倦怘感, 神経系障 害, 味覚異常の 3 項目は改善率が下位であり, 特 に神経系障害と味覚異常は改善率が 2 割以下で あった。

表 1 調査項目別の Grade, FS 改善率

\begin{tabular}{|c|c|c|c|}
\hline & \multicolumn{3}{|c|}{ 件数 (\%) } \\
\hline 項目 (件数) & 改善 & 不変 & 悪化 \\
\hline 疼痛 (15) & $12(80.0)$ & $3(20.0)$ & $0(0.0)$ \\
\hline 口腔粘膜炎 (37) & $25(67.6)$ & $12(32.4)$ & $0(0.0)$ \\
\hline 皮膚症状 (30) ※ & $19(63.3)$ & $10(33.3)$ & $1(3.3)$ \\
\hline 手足症候群 (12) & $7(58.3)$ & $5(41.7)$ & $0(0.0)$ \\
\hline 爪用炎(11) & $6(54.5)$ & $5(45.5)$ & $0(0.0)$ \\
\hline 便秘 (21) · 下痢 (27) & $25(52.1)$ & $22(45.8)$ & $1(2.1)$ \\
\hline 悪心(36）・嘔吐 (6) & $21(50.0)$ & $20(47.6)$ & $1(2.4)$ \\
\hline 倦怠感 (28) & $13(46.4)$ & $14(50.0)$ & $1(3.6)$ \\
\hline 神経系障害(29) & $5(17.2)$ & $24(82.8)$ & $0(0.0)$ \\
\hline 味覚異常 (14) & $2(14.3)$ & $10(71.4)$ & $2(14.3)$ \\
\hline
\end{tabular}

\section{考察}

外来化学療法室を利用する診療科は多岐にわた るため, 安全に施行するためには幅広いマネジメ ントが必要になる。多職種によるチーム医療が必 要とされているなかで, 薬剤師の外来がん化学療 法への介入効果を調査することは有意義であると 考えられる。

今回は処方提案の根拠として各薬剤のアルゴリ ズムや各学会のガイドラインを参照し, 薬剤師が スムーズな介入を行ううえでの一助となった。し かし提案すべき薬剤が症例に対して禁忌である場 合など，アルゴリズムやガイドラインが適応とな らない状況も存在した。 そのような状況では, 化 学療法室担当の薬剤師同士で協議および意見統一 を行い, 適切と考える処方を立案した後, 提案を 行った. 従って, 提案した処方の効果が薬剤師各々 の技能に依存していることはないと考えられる.

吉見らは薬剂師が医師の診察前に介入すること の有用性を報告しており, そのなかで処方提案採 用率は $94 \%$ であると報告している. ${ }^{5)}$ 本調查期間 では薬剤師による処方提案は $95.8 \%$ が採用され た。当院でも医師の診察前に薬剤師が介入を行っ ている. 薬剤師が提案した薬剤が害際に患者に投 与されるためには，まず薬剤師による処方提案が 医師に採用される必要がある. 医師の診察後に処 方提案を行いそれが採用となる場合, 一度決定さ れた処方を変更する必要があり, 医師, 薬剂師共 にストレスになると考えられる。医師の診察前に 薬剤師が介入を行ったことでそのようなストレス 
がなくなり，高い提案採用率を得ることが可能と なったと考えられる。改善率には処方提案の質が 影響するが，その初期段階として処方の提案採用 率を上昇させるために医師の診察前に薬剂師が介 入を行うことが必須と考えられる。

今回定量的に検討を行い, 薬剤師の介入前に比 べ，薬剤師の介入後において Grade, FSいずれ のスコアも有意に改善が得られた。従って外来が 几化学療法に薬剂師が介入することは, 抗がん剤 治療の限定的な副作用だけではなくがん性疼痛な どの早期の緩和ケアの施行を含めたがん診療全般 に有用であると考えられる。

Grade 評価抒よび FS 評価を用いた改善率は $50.8 \%$ あっったが, Grade 評価は不変でも自覚症 状の改善が得られた改善率は $69.5 \%$ であり, 約 $70 \%$ 案件について薬荗師が介入することで症状 の改善が得られた。CTCAE ver.4.0の Grade 評価 については，支持療法を行い改善が認められた例 でも, Grade は不変と評価される例が存在する. 今回 Grade 評価および FS 評価を用いた改善率 (50.8\%) に比べ, 自覚症状の改善が得られた改 善率（69.5\%）が高かったのは，このような事例 があることも要因であると思われる，従って，副 作用㧍よび疼痛の評価方法について再検討する必 要があると考えられる。

有害事象改善率に関しては, 疼痛, 口脉粘膜炎, 皮膚症状が上位であった。上記の項目は, 各薬剤 の適正使用ガイドなどのアルゴリズムが構築され 始めており, 薬剂師が介入しやすいと考えられる.

しかし, 味覚異常や神経系障害は Grade の改善 を認めた症例の割合は少なかった，抗がん剤によ る味覚異常に関しては，ポラプレジンクなどの有 用性の報告 ${ }^{6,7)}$ が散見されるが，発症メカニズム に関する知見もそしく効果的な対症療法は確立さ れていない，石川らは外来がん化学療法に伴う味 覚異常を認めた患者のうち， 66.7\%に食思低下が 認められ, 味覚異常の発現は患者の quality of life （QOL）を著しく低下させる可能性があることを 報告している. ${ }^{8)}$ しかし CTCAE ver.4.0では，味覚 異常は Grade 2 までの評価となっており, 各レジ メンの減量基準では Grade 3 まで減量や中止を行 わない場合が多い。これらのことは味覚異常を悪
化させ, 遷延させる要因となると思われる．また， 抗がん剂による神経系障害に対し, 当院では牛車 腎気丸やプレガバリンなどが使用されることが多 い．最近ではデュロキセチンの有用性の報告もあ るが, ${ }^{9}$ 対処に難渋する例が多く, 味覚異常と同 じく効果的な支持療法は確立されていない。これ らの副作用については支持療法について再検討 や, 治療効果を考慮しながら原因薬剤の減量およ び中止など支持療法以外の対処法を検討する必要 がある.

今回の薬剤師の介入時点は必ずしも化学療法施 行の第 1 クールではなく, 事前に医師などの介入 が行われていたケースも存在する. しかし, 今回 の対象症例については薬剤師が副作用モニタリン グを行い，無効と判断した症例に対して処方提案 を行った. 従って, 今回の結果には医師などの事 前の介入が影響していることはないと考えられ る. また, 今回の調查方法では, 薬剂師が「薬剤 師介入前」のクールで処方の提案を行い採用され， 「薬剂師介入後」のクールでも処方提案を行い採 用された場合, その処方の効果は共に「薬剤師介 入後」に影響している可能性がある.

今後は支持療法に使用した薬剤の種類や用法用 量, 薬片師の介入時期などに関してさらなる調査 が必要である。また，今回の調査は単施設での調 査であり, 各副作用症状の評価症例数は限りが あった，今後は当院を含む多施設での調查も必要 と考える.

今回得られた結果を引き続きデー夕集積し分析 を行うことで，院内の副作用対策やクリニカルパ スを作成し，がん患者指導管理料の算定に活用し ていきたいと考える，また，それに基づいて提案 していく体制を確立していくことが今後の課題と 考えられる.

\section{利益相反}

開示すべき利益相反はない。

\section{引用文献}

1）中島輝一, 真野泰成, 大内か抢り, 佐藤大輔, 岩田 
杏子, 樋口安耶, 江原邦明, 加藤芳徳, 廣澤伊織, 田島正教, 土屋文人, 山田治美, 小瀧 一, 旭満 里子, 外来がん患者に対する薬剤師外来の役割 とその評価, 医療薬学, 2012, 38, 599-608.

2) Iihara $H$, Ishihara $M$, Matsuura $K$, Kurahashi S, Takahashi T, Kawaguchi Y, Yoshida K, Itoh Y, Pharmacists contribute to the improved efficiency of medical practices in the outpatient cancer chemotherapy clinic, J Eval Clin Pract, 2011, 18, 753-760.

3）前勇太郎, 横川貴志, 川上和宜, 八木奈央, 末永 光邦, 篠崎英司, 松阪 諭, 水沼信之, 濱 敏弘, XELOX療法における薬剂師外来の有用性, 医療 薬学, 2011, 37, 611-615.

4）須藤正朝, 森井博朗, 阪中美紀, 野田哲史, 若杉 吉宣, 福竹法子, 河合由紀, 目片英治, 寺田智祐, 外来がん化学療法における服薬指導業務の導入 とその効果, 医療薬学, 2013, 39, 77-84.

5）吉見千明, 山田摩耶, 藤井宏典, 西垣美奈子, 飯原 大稳, 北市清幸, 高橋 茲, 倉橋小代子, 高橋孝夫, 吉田和弘, 伊藤善規, 外来がん化学療法室での チーム医療における薬剤師の役割 診察前患者 面談の有用性評価, 癌と化学療法, 2013, 40, 349354.
6) 池田 稔, 黒野祐一, 井之口昭, 武田憲昭, 愛場 庸雅, 野村泰之, 阪上雅史, プラセボ対照無作為 化試験による亜鉛欠乏性または特発性味覚障害 219例に対するポラプレジンク投与の臨床的検 討, 日本耳鼻咽喉科学会会報, 2013, 116, 17-26.

7）中多陽子, 平島智徳, 金銅葉子, 徳岡良恵, 今里 仁美, 岩田 香, 大森由佳理, 大和章宏, 清水 三郎, 長尾貞子, 松井 薰, 阿部典子, 胸部悪性腫 瘍治療中の味覚障害における亜鉛の関与とポラ プレジンクロ腔内崩壊錠の効果 レトロスペク ティブスタディ, 癌と化学療法, 2008, 35, 955-959.

8）石川 徹, 森田純子, 河内啓子, 田頭尚士, アン ケート調査による外来がん化学療法に伴う味覚 異常の発生に関する検討, 癌と化学療法, 2013, 40, 1049-1054.

9) Ellen SM, Herbert P, Constance C, Stewart F, Electra PD, Tim A, Linda BR, Camilo FE, Chetaye K, Nguyet LL, Paul GB, Charles SI, Effect of duloxetine on pain, function, and quality of life among patients with chemotherapy-induced painful peripheral neuropathy, JAMA, 2013, 309, 1359-1367. 